\title{
Pengembangan Produk Usaha dan Intelektual Kampus di Universitas PGRI Semaranag
}

\author{
Mila Karmila ${ }^{*}$, Purwadi $^{2}$, Muhtarom ${ }^{3}$
}

1,2,3 Universitas PGRI Semarang

\section{A R T I C L E I N F O \\ Article history: \\ Received 20 May 2019 \\ Received in revised form 10 June 2019 \\ Accepted 30 July 2019 \\ Available online 30 August 2019 \\ Kata Kunci: \\ Daycare, Nursery, music, \\ early childhood education \\ Keywords: \\ Taman Pengasuhan Anak, perawatan, anak usia dini, musik}

\begin{abstract}
A B S T R A K
Tujuan dari kegiatan PPUPIK ini adalah menumbuhkan sifat kewirausahaan untuk memperoleh profit sebagai tambahan sumber pemasukan Universitas PGRI Semarang, dapat meringankan beban ibu-ibu dalam mengasuh dan merawat anak, sehingga para ibu lebih fokus, tenang dan nyaman dalam bekerja. Lebih lanjut, program PPUPIK juga berfungsi sebagai laboratorium bagi mahasiswa PAUD untuk meningkatkan kompetensi pedagogik dan kompetensi profesioanl secara praktis,. Sedangkan tujuan khususnya adalah mendirikan PENA PRIMA secara terpadu dan bertahap yang nantinya menjadi imagebrand dari Program Studi PGPAUD Universitas PGRI Semarang. Luaran yang akan dihasilkan unit PPUPIK dalam tahun ketiga ini adalah SIM berbasis Hybrid PENA PRIMA Apps, NPSN, sinkronisasi DAPODIK, pendaftaran Akreditas BAN PAUD PNF, target terakreditasi A pada tahun 2021.jumlah siswa TPA sebanyak 30 anak, dan Sekolah musik Pena Prima dengan 10 peserta didik.
\end{abstract}

\section{A B S T R A C T}

The purpose of this PPUPIK activity is to foster entrepreneurial traits to gain profit as an additional source of income from the University of PGRI Semarang, to ease the burden on mothers in caring for and caring for children, so that mothers are more focused, calm and comfortable in working. Furthermore, the PPUPIK program also functions as a laboratory for early childhood education students to improve their pedagogical and professional competencies practically. While the specific goal is to establish PENA PRIMA in an integrated and gradual manner which later will become an imagebrand of the early childhood education Study Program, PGRI University, Semarang. The outputs that will be produced by PPUPIK units in the third year are Hybrid PENA PRIMA Apps SIM, NPSN, DAPODIK synchronization, PNAN PAUD Accreditation registration, accredited target in 2021.The number of TPA students is 30 children, and Pena Prima music school with 10 students.

\footnotetext{
* Corresponding author.

E-mail addresses: mila45@gmail.com (Mila Karmila)
} 


\section{Pendahuluan}

Pengembangan produk dan inovasi merupakan sebuah hal penting yang dibutuhkan oleh perusahaan. Perusahaan menjalankan bisnis pasti dengan adanya pesaing di luar perusahaan. Maka dari itu proses ini penting agar perusahaan mempunyai produk yang berbeda dengan pesain dan memiliki keunggulan yang menonjol, sehingga membuat orang tertarik dengan produknya (Wijaya, 2013).

Unit Usaha yang berhasil dikembangkan melalui program PPUPIK pada tahun ke tiga ini adalah Taman Penitipan Anak (TPA) Ramah Anak dengan nama "PENA PRIMA" (Pendidikan Anak Berpribadi Mulia) berperspektif hak anak, dan kegiatan ekstra kulikuler serta sekolah musik PENA PRIMA, dan paket program Liburan. Dalam rangka peningkatan pelayanan terhadap anak-anak usia dini baik secara formal maupun non formal, salah satu bentuk layanan PAUD adalah Taman Penitipan Anak (TPA) atau Day Care. TPA merupakan wahana kesejahteraan yang berfungsi sebagai pengganti keluarga untuk jangka waktu tertentu bagi anak yang orang tuanya bekerja. TPA ini menyelenggarakan program pendidikan, perawatan sekaligus pengasuhan bersama terhadap anak sejak lahir sampai dengan usia enam tahun (dengan prioritas anak usia enam tahun ke bawah) (Dirjen PAUDNI,2013).

Secara eksternal program pengasuhan anak (Day Care/Tempat Penitipan Anak) diperlukan untuk memberikan layanan kepada masyarakat secara luas. Hal ini terkait dengan semakin banyaknya wanita atau ibu yang tidak hanya berfungsi sebagai pendamping suami dan pengasuh anak dalam keluarga tetapi juga berfungsi sebagai pencari nafkah. Data statistik menunjukkan bahwa pada tahun 2000 terdapat 101,6 juta angkatan kerja dan 40\% di antaranya (40,6 juta) adalah para angkatan kerja wanita (BPS: 2000 dalam http://tk.labschool.upi.edu/daycare/). Data hasil survei angkatan kerja nasional (Sakernas) tahun 2001 menunjukkan jumlah wanita bekerja tiap tahun bertambah 1,18\%. Hal ini berakibat negatif terhadap layanan pendidikan, pengasuhan dan perawatan yang seharusnya diperoleh anak dari keluarga dalam hal ini orang tua. Apabila kedua orang tua sama-sama bekerja maka fungsi pelayanan, pengasuhan dan pendidikan anak secara otomatis akan berkurang. Kondisi demikian tentu saja berdampak buruk terhadap proses tumbuh kembang anak.

Disisi lain, Undang-Undang No 13 Tahun 2013 tentang ketenagakerjaan pasal 83 menyebutkan bahwa tenaga kerja berhak mendapatkan cuti melahirkan 1,5 bulan sebelum melahirkan dan 1,5 bulan sesudah melahirkan. Setelah masa cuti tersebut, para ibu harus kembali ke rutinitas pekerjaan sehingga menjadi penyebab keterbatasan bagi ibu yang dalam mengasuh anak, harus meninggalkan anaknya selama bekerja dan kesulitan mendapat pengasuh yang tepat untuk anaknya menjadikan kecemasan dan kehawatiran tersendiri bagi para pekerja wanita tersebut.

Mengamati perkembangan pada tahun pertama, antusias masayarakat untuk memasukan anaknya ke TPA PENA PRIMA semakin meningkat. Hal tersebut terlihat dengan jumlah murid baru yang terus bertambah setiap bulan dan tahunnya. Perkembangan tersebut membuktikan tingkat kepercayaan masayrakat terhadap TPA PENA PRIMA semakin baik. Berbagai keunggalan, kemudahan dan fleksibilitas layanan TPA PENA PRIMA menjadikan nilai tambah kepada masyarakat.

Keunggulan TPA PENA PRIMA lainnya adalah menjadi model TPA yang Ramah Anak, yaitu TPA yang dalam pelayanannya memberikan dan memperhatikan pemenuhan serta perlindungan hak anak. Penyelenggaraan TPA dengan unggulan ramah anak yaitu penyelenggaraan layanan berperspektif hak anak, yang didasarkan pada prinsip dan azas/prinsip hak anak, yang terdiri dari: non diskriminasi; kepentingan terbaik untuk anak, pemenuhan hak anak untuk hidup, kelangsungan hidup perkembangan serta penghargaan terhadap pandangan anak. (BP3AKB, 2016:10). Adapun unggulan lainnya yang dimiliki TPA PENA PRIMA adalah layanan operasional yang fleksibel (disajikan dalam Tabel 1.1.), adanya latihan stimulasi musik selama belajar di TPA PENA PRIMA, anak mendapatkan pengasuhan, perawatan dan pendidikan yang tepat karena TPA PENA PRIMA memiliki pendidik yang terampil berkualifikasi pendidikan anak usia dini serta telah mendapatkan pelatihan pengasuhan dan perawatan Batita bekerja sama dengan Ikatan Bidan Indonesia (IBI) Indonesia.

Layanan Usaha yang dikembangkan di tahun ketiga yang merupakan Unggulan TPA PENA PRIMA yaitu Sekolah musik PENA PRIMA. Dasar dari pengembangan layanan usaha tersebut adalah permintaan mayoritas orangtua sebagai respon dari kegiatan ekstra kulikuler bermain musik yang diselenggarakan. Musik merupakan hal terpenting dalam kehidupan sehari - hari dari awal bangun tidur sampai tidur lagi. Lwin, dkk (2008 : 137) mengemukakan bahwa musik merupakan aspek pertama yang harus dikembangkan dari sudut neurologis. Karena sejak dari dalam kandungan janin sudah bisa mendengarkan suara- suara termasuk juga musik. Dari semua kecerdasan yang ada dalam diri seseorang, musik memberikan pengaruh terbesar untuk diri manusia dan bisa mengembangkan kecerdasan lainnya. Sehingga aspek kecerdasan musik pada anak sangat penting untuk dikembangkan agar kecerdasan yang lainnnya bisa berkembang dengan baik. 
Menurut Sousa (2012:258) musik memberikan efek yang kuat pada otak dengan cara menstimulasi intelektual dan emosional. Musik juga dapat mempengaruhi tubuh dengan cara mengubah kecepatam detak jantung, kecepatan bernapas, tekanan darah, ambang batas rasa sakit, dan gerakan otot. Berbagai respon tersebut dihasilkan dari aktivitasi jaringan- jaringan saraf yang terlibat dalam motivasi dan rasa senang. Oleh karena itu, untuk perkembangan anak usia dini yang lebih baik perlu mengembangkan aspek kecerdasan musikalnya terlebih dahulu. Penting bagi pendidik atau orang tua untuk mengetahui manfaat kecerdasan musikal pada anak agar keterampilan- keterampilan yang lain dapat berkembang optimal.

Pendidikan seni musik merupakan pendidikan yang memberikan kemampuan mengekspresikan dan mengapresiasikan seni secara kreatif untuk pengembangan kepribadian siswa dan memberikan sikap-sikap atau emosional yang seimbang.

Pendidikan seni musik di PAUD dapat dijadikan sebagai salah satu jalan efektif dalam mengembangkan talenta anak dan membina anak usia dini agar dapat tumbuh dan berkembang sesuai dengan bakat dan minatnya, pendidikan seni musik dijadikan sarana ekspresi, imajinasi, kreativitas dan apresiasi musik anak. Konsep dasar pendidikan seni musik bagi anak meliputi kemampuan fisik, bahasa, sosial, emosional, kognitif. Tujuannya adalah lebih membantu anak untuk mampu mengungkapkan apa yang anak ketahui dan rasakan melalui seni. Pendidikan seni musik penting dilaksanakan di PAUD karena melalui pendidikan musik dapat mengembangkan dan meningkatkan kualitas anak didik dalam pendewasaan. Pengertian ini didukung oleh pendapat, yaitu:

Pada Tahun ketiga ini TPA PENA PRIMA dilengkapi dengan fasilitas yang lebih representatif bagi anak mulai dari usia 3 bulan sampai dengan 6 tahun. Adapun fasilitas yang tersedia adalah: Ruang kelas yang dilengkapi dengan berbagai alat permainan edukatif, media pembelajaran, ruang makan untuk kegiatan makan bersama, kuri makan bayi, Batita, ruang tidur dengan 30 tempat tidur bayi dan anakanak, halaman luas, alat permainan panjatan, area pasir, dan toilet yang bersih dan ramah anak, sepda dan otopet untuk kegiatan pengembangan motorik kasar anak.

\section{Metode}

Pelaksanaan PPUPIK PENA PRIMA pada tahun ketiga dapat dideskripsikan sebagai berikut: dideskripsikan komponen-komponen rencana usaha kegiatan sebagai berikut:

1. Bahan Baku

a. Bayi dan balita atau disebut anak usia dini, yaitu anak dengan usia 3 bulan sampai dengan 6 tahun, yang akan diberikan layanan pengasuhan bersama, perawatan, dan pemberian stimulasi edukasi sesuai dengan tahapan perkembangan usianya dan perlakuan penuh dengan kasih sayang serta kehangatan dengan tetap menjaga profesionalisme pendidik PAUD.

b. Peralatan yang digunakan dalam jasa TPA PENA PRIMA ini akan disesuaikan dengan standar minimum pelayanan Taman Penitipan Anak yang tertuang Peraturan Menteri Pendidikan dan Kebudayaan Nomor 137 tahun 2014 tentang Standar tingkat pencapaian anak usia dini.

c. Peralatan dalam jasa antar jemput, adalah kendaraan dan buku administrasi

d. Peralatan Sekolah Musik PENA PRIMA adalah, tempat bermain musik yakni laboratorium musik, peralatan musik seperti keayboard, drum, Angklung, Xylophone, dan Guitar, Mixer sound system, alat rekaman

e. Peralatan dalam jasa layanan tumbuh kembang anak adalah, para pakar pendidikan anak usia dini yang juga merupakan dosen tetap PAUD, psikolog, dan konselor.

f. Agar usaha PENA PRIMA yang berupa layanan TPA, jasa antar jemput anak, dan sekolah musik serta layanan tumbuh kembang anak dapat berjalan dengan baik, maka disusun buku panduan mengenai standar operasional prosedur (SOP) masing-masing layanan tersebut.

2. Produksi

Pada Tahun kedua, PENA PRIMA Universitas PGRI Semarang memiliki 1 ruang kantor kepala, 2 ruang kelas, 1 ruang tengah dan dapur, 2 ruang tidur, halaman bermain, area pasir, 1 kamar mandi serta 1 ruang laboratorium PAUD dan internet room yang berkapasitas masing-masing untuk 20 orang). Rencana pengembangan ruang PENA PRIMA Universitas PGRI Semarang adalah $\pm 60 \mathrm{~m} 2$ dipergunakan sebagai ruang kelas dengan kapasitas 20 anak lengkap dengan fasilitas audio visual, studio musik untuk mempercepat tumbuh kembang anak melalui musik. Selanjutnya ruang seluas $40 \mathrm{~m} 2$ direncanakan untuk pengembangan ruang belajar anak lengkap dengan fasilitasnya sesuai dengan Peraturan Menteri Pendidikan dan Kebudayaan Nomor 137 tahun 2014 tentang standar tingkat pencapaian anak usia dini.

Selanjutnya produk hasil layanan PPUPIK PENA PRIMA diantaranya: 1) Buku komunikasi harian untuk menyampaikan kegiatan harian di TPA PENA PRIMA kepada orang tua, 2) Kurikulum TPA PENA PRIMA Ramah Anak, 3) Rencana program pembelajaran harian (RPPH), 4) Buku pencatatan pengamatan, 5) Laporan tumbuh kembang anak yang disampaikan per semester, 6) Sertifikat telah menjadi peserta 
didik TPA PENA PRIMA, 7) Buku Standar Operasional Prosedur PENA PRIMA, dan 8) Sistem Informasi Manajemen (SIM) digital, PENA PRIMA Apps

\section{Proses Produksi}

Usaha utama yang akan dikembangkan oleh PPUPIK PENA PRIMA Pendidikan Anak Berpribadi Mulia adalah jasa pendidikan dan jasa pelayanan sehingga ujung tombaknya adalah pelayanan prima (prime service). Oleh karenanya, aliran usaha harus dibuat secara terintegrasi dengan proses pengendalian kualitas seperti tampak pada Seluruh proses diawali dengan proses marketing untuk mencari calon pelanggan (client). Setelah calon pelanggan diperoleh, maka dilakukan analisis terhadap kebutuhan calon pelanggan tersebut. Berdasarkan analisis tersebut, dapat dilakukan perumusan kebutuhan pelanggan, yang dilanjutkan dengan persiapan fasilitas usaha. Setelah itu, dilakukan pelaksanaan kegiatan sesuai rencana yang telah disusun. Setiap minggu dilakukan evaluasi dan analisis hasil yang dikomunikasikan kembali dengan pelanggan. Siklus proses yang seperti ini dilakukan secara penuh dan berulang untuk seluruh jenis usaha akan dilakukan oleh PENA PRIMA. Mekanisme evaluasi dan feedback merupakan mata rantai pengendalian terhadap kualitas pelatihan yang dilaksanakan oleh PENA PRIMA, yang akan berdampak pada peningkatan kualitas secara berkelanjutan.

\section{Manajemen}

Jasa layanan PENA PRIMA merupakan usaha yang terintegrasi dalam memberikan pelayanan holistic bagi anak usia dini yang meliputi, layanan menjemput anak ke TPA, memberikan pengasuhan dan perawatan dalam program TPA diintegrasikan dengan kegiatan ekstra kulikuler bermain musik dan layanan konsultasi tumbuh kembang anak.

\section{Pemasaran}

Untuk menunjang pengembangan dari usaha PENA PRIMA, diperlukan strategi pemasaran yang tepat dan terencana dengan baik. Kegiatan unit usaha PENA PRIMA ditujukan untuk masyarakat umum, pemasaran dilakukan dengan menyebarkan informasi seluas-luasnya. Beberapa metode pemasaran digunakan antara lain a). Positioning statement, b). Pricing strategy, c). Promotion strategy, d). Developing relationship dan e). Sumber daya manusia.

\section{Fasilitas}

Tahun 2019, unit PPUPIK PENA PRIMA telah memiliki tempat dan fasilitas TPA PENA PRIMA (1 ruang kantor, 2 kelas, 2 ruang tidur, 1 ruang tengah dan dapur, ruang makan, Lab. Musik, halaman bermain dan 1 toilet); penambahan fasilitas bermain: play ground, kursi makan anak, box tidur bayi (untuk 3-6 bulan), penambahan fasilitas alat musik berupa piano, gamelan pesawat, drum band anak, perkusi musik kabasa, Rebana, keyboard, Ampli Player, TV LED dan DVD player untuk mendukung tahap tumbuh kembang anak. Air Purifier, Sepeda anak, otopet, berbaai APE yang mendukung stimulasi tumbh kembang anak.

\section{Finansial}

Untuk menilai kelayakan investasi usaha PENA PRIMA dilakukan berdasarkan nilai Net Present Value (NPV), Net Benefit/Cost Ratio (Net B/C), Internal Rate Ratio (IRR) dan Payback Period (PBP). Nilai kriteria-kriteria tersebut dapat dijelaskan pada Tabel 3.3. Perhitungan kriteria NPV, Net B/C Ratio dan IRR menggunakan Discout Factor (DF) 16\%. Hal ini didasarkan pada tingkat suku bunga pinjaman per tahun yang dikenakan Bank.

\section{Hasil dan pembahasan}

Berdasarkan Hasil kegiatan PPUPIK PENA PRIMA pada tahun ketiga antara lain konsisten melakukan koordinasi bersama tim PPUPIK untuk evaluasi setiap bulan sebagai refleksi kegiatan PPUPIK. Kegiatan koordinasi bulan pertama dilakukan untuk menyusun pelaksanaan kegiatan di setiap layanan usaha, ataupun melakukan evaluasi untuk layanan usaha yang sudah berjalan. Adapun hasil kegitaan lainnya dapat dideskripsikan berikut ini:

\section{Pelaksanaan lokakarya pengembangan Kurikulum TPA RAMAH ANAK PENA PRIMA}

Kegiatan pada tahun ketiga yang dilakukan Tim PPUPIK dalam mengembangkan dan meningkatkan layanan usaha ini adalah adalah dengan melakukan peninjauan kurilum TPA PENA PRIMA yang ramah anak. Rangkaian kegiatan yang dilakukan dintaranya dengan mengadakan Rapat koordinasi antara direktur dengan kepala TPA untuk membentuk tim peninjauan kurikulum. Setelah itu melakukan rapat 
dengan seluruh personalia, yakni kepala sekolah, guru dan asisten TPA PENA PRIMA Untuk menentukan waktu lokakarya peninjauan kurikulum.

Hasil dari lokakarya dan workshop tim dengan kepala TPA, guru dan asisten adalah tersusunnya dokumen kurikulum TPA Ramah Anak PENA PRIMA, yang akan digunakan dan diimplemenetasikan dalam pemberian layanan setiap hari sesuai dengan kelompok usia yakni 3-6 bulan, 6-9 bulan, 9-12 bulan, 12-18 bulan, 18-24 bulan, 24-36 bulan, 36-48 bulan, 48-60 bulan, 60-72 bulan. Dokumen kurikulum juga berisi program pengembangan dan muatan materi pembelajaran untuk anak usia dini dengan menggunakan pembelajaran yang terpadu, Holistik Integratif dengan pendekatan tematik dan pembiasaan. Adapaun program tahunan dan program Holistik Integratif yang sudah disusun dapat dilihat pada tabel berikut

Tabel 1. Program Tahunan Holistik Integratif

\begin{tabular}{|c|c|c|c|c|}
\hline NO & PROGRAM KEGIATAN & $\begin{array}{c}\text { INTENSITAS } \\
\text { PELAKSANAAN }\end{array}$ & WAKTU & KETERANGAN \\
\hline \multirow[t]{12}{*}{1} & $\begin{array}{l}\text { HAK PROVISI (ketersediaan } \\
\text { kebutuhan anak ), seperti: } \\
\text { Kasih Sayang } \\
\text { a. Layanan penuh kasih } \\
\quad \text { sayang }\end{array}$ & $\begin{array}{l}\text { Terintegrasi dalam } \\
\text { pembelajaran }\end{array}$ & $\begin{array}{l}\text { Setiap hari } \\
\text { layanan } \\
\text { operasional }\end{array}$ & \\
\hline & $\begin{array}{l}\text { Layanan Gizi } \\
\text { b. } \\
\text { PMTAS (Program } \\
\text { Makanan Tambahan } \\
\text { Anak Sekolah) }\end{array}$ & Setiap Bulan & Minggu ke 4 & $\begin{array}{l}\text { Jadwal menu PMTAS } \\
\text { terlampir }\end{array}$ \\
\hline & $\begin{array}{l}\text { c. Gerimis (Gerakan } \\
\text { Minum Susu bersama) }\end{array}$ & Setiap Bulan & Minggu ke 2 & $\begin{array}{l}\text { Anak yang tidak biasa } \\
\text { minum susu tidak } \\
\text { dipaksakan }\end{array}$ \\
\hline & Layanan Kesehatan & & Februari dan & Bermitra dengan \\
\hline & $\begin{array}{l}\text { e. Pemeriksaan } \\
\text { kesehatan }\end{array}$ & Setiap bulan & Minggu ke 1 & \\
\hline & $\begin{array}{ll}\text { f. Pemeriksaan } \\
\text { kebersihan diri }\end{array}$ & Setiap Minggu & Hari Senin & \\
\hline & g. Pemeriksaan gigi & 6 bulan sekali & $\begin{array}{l}\text { Juli dan } \\
\text { Januari }\end{array}$ & $\begin{array}{l}\text { Bermitra dengan } \\
\text { Klinik kampus }\end{array}$ \\
\hline & $\begin{array}{l}\text { h. Deteksi Dini Ttumbuh } \\
\text { Kembang Anak }\end{array}$ & 3 bulan sekali & $\begin{array}{l}\text { Agustus, } \\
\text { Nopember, } \\
\text { Maret Juni }\end{array}$ & $\begin{array}{l}\text { Bermitra dengan } \\
\text { Klinik kampus }\end{array}$ \\
\hline & $\begin{array}{l}\text { i. Peningkatan prasarana } \\
\text { pendidikan Ramah } \\
\text { anak }\end{array}$ & 6 bulan sekali & $\begin{array}{l}\text { Akhir } \\
\text { semester }\end{array}$ & \\
\hline & $\begin{array}{l}\text { Layanan } \\
\text { Kesejahteraan/Rekreasi: } \\
\text { j. Bermain, }\end{array}$ & $\begin{array}{l}\text { Terintegrasi dalam } \\
\text { pembelajaran }\end{array}$ & $\begin{array}{l}\text { Setiap hari } \\
\text { layanan } \\
\text { operasional }\end{array}$ & $\begin{array}{l}\text { Bermain dalam dan } \\
\text { luar ruangan, atau } \\
\text { sekitar lingkungan } \\
\text { kampus }\end{array}$ \\
\hline & $\begin{array}{l}\text { k. Karyawisata /Outing } \\
\text { Class/ }\end{array}$ & 1 tahun sekali & $\begin{array}{l}\text { Puncak tema } \\
\text { Lalu Lintas }\end{array}$ & \\
\hline & $\begin{array}{l}\text { 1. Memanfaatkan } \\
\text { lingkungan sambil } \\
\text { belajar }\end{array}$ & $\begin{array}{l}\text { Terintegrasi dalam } \\
\text { kegiatan Outing }\end{array}$ & $\begin{array}{l}1 \text { bulan sekali } \\
\text { minggu k } 2\end{array}$ & $\begin{array}{l}\text { Mengunjungi kegiatan } \\
\text { kampus }\end{array}$ \\
\hline \multirow[t]{4}{*}{2} & $\begin{array}{l}\text { Proteksi (Hak mendapatkan } \\
\text { perlindungan) }\end{array}$ & & & \\
\hline & $\begin{array}{l}\text { a. Penyusunan Standar } \\
\text { Operasional untuk } \\
\text { setiap kegiatan }\end{array}$ & 1 tahun sekali & Bulan Juni & $\begin{array}{l}\text { Terdokumentasikan } \\
\text { dalam SOP PENA } \\
\text { PRIMA }\end{array}$ \\
\hline & $\begin{array}{l}\text { b. Pemasangan layanan } \\
\text { informasi kesehatan } \\
\text { bagi anak pada papan } \\
\text { informasi }\end{array}$ & 1 bulan sekali & $\begin{array}{l}\text { Mingu } \\
\text { pertama }\end{array}$ & Tertempel di dinding \\
\hline & c. Pemasangan poster & 1 bulan sekali & Mingu & Tertempel di papan \\
\hline
\end{tabular}


pencegahan kekerasan

pada anak

d. Integrasi Nilai

karaktetr dalam

pembelajaran

3
a. Mengikutsertakan anak dalam kegiatan pembelajaran
b. Pojok Rencana

$\begin{array}{lll} & \text { pertama } & \text { informasi } \\ \text { Terintegrasi dalam } & \text { Setiap hari } & \\ \text { RPPH } & & \\ & & \\ \begin{array}{l}\text { Terintegrasi dalam } \\ \text { pembelajaran }\end{array} & \text { Setiap hari } & \\ \begin{array}{l}\text { Terintegrasi dalam } \\ \text { pembelaajran }\end{array} & \text { Setiap hari } & \begin{array}{l}\text { Anak memilih bermain } \\ \text { bebas seperti apa } \\ \text { sesuai dengan hobinya }\end{array}\end{array}$

\section{Pengumpulan Sumber Bahan Baku}

Kegiatan Pengumpulan Sumber Bahan Baku tahun ketiga dilakukan dengan belanja alat dan bahan yang sudah mulai dilakukan sejak bulan Januari sampai dengan bulan Agustus, meliputi belanja alat dan bahan, pengadaan sarana prasarana baik untuk Taman penitipan Anak maupun untuk layanan usaha sekolah musik PENA PRIMA Belanja diantaranya: pembelanjaan untuk sarana prasarana di ruang tidur, pembelanjaan di ruang kelas seperti Air Purifire, di Ruang Makan, alat bermain Playground di luar ruangan, dan perlengkapan untuk pusat multi media. Selain itu pengadaan bahan baku sekolah musik TPA PENA PRIMA berupa penambahan alat musik keayboard, drum, beberapa Guitar, Rebana dan Ampli Player. Beberapa contoh pengadaan sumber bahan baku, tersaji dalam gambar berikut ini:
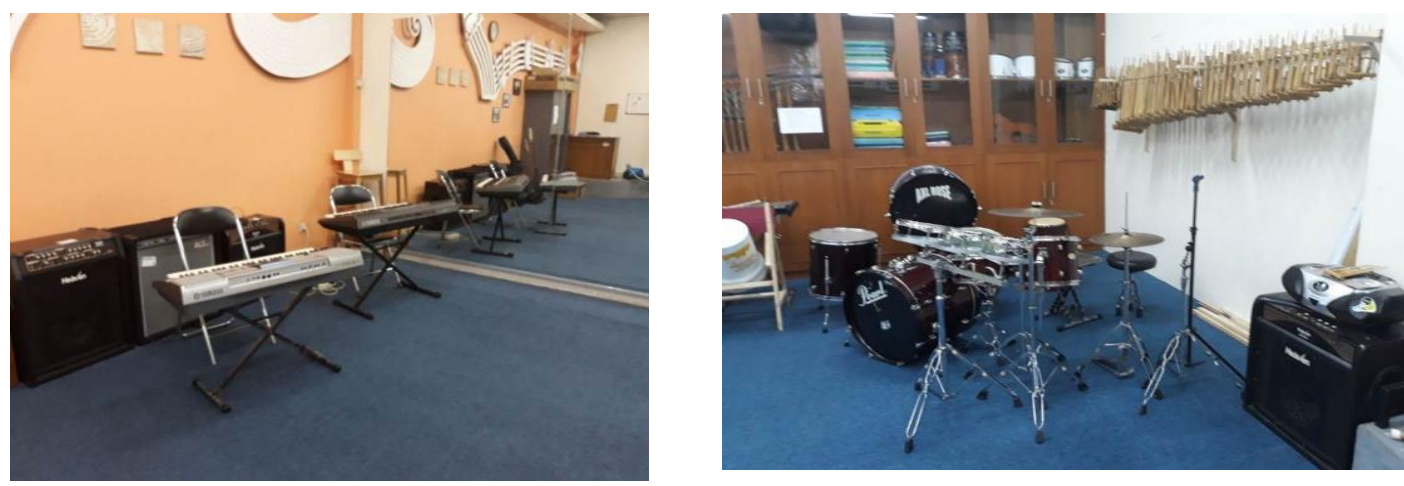

Gambar 1. Alat Musik Keyboard untuk mendukung ekstrakulikuler Musik PENA PRIMA

3. Penyusunan Standar Operasional Prosedur (SOP) Usaha

Kegiatan selanjutnya yaitu melengkapi Standar Operasional Prosedur usaha yang sudah meliputi, penyusunan kurikulum TPA PENA PRIMA yang terdiri dari penyusunan Tingkat Pencapaian Perkembangan (TPP), penyusunan program stimulasi, penyusunan perencanaan pembelajaran baik dari program tahunan, bulanan, mingguan dan harian.

\section{Melakukan Analisis Kebutuhan Pasar}

Pelaksanaan analisis kebutuhan pasar dilakukan dengan melengkapi rencana usaha (bussiness plan) PENA PRIMA. Dalam rencana usaha tersebut dideskripsikan mengenai profil usaha PENA PRIMA. Profil tersebut mendeskripsikan sejarah berdirinya usaha, visi, misi dan tujuan usaha.

\section{Pemasaran Usaha}

Kegiatan pemasaran usaha pada tahun ketiga relatif lebih mudah karena kepercayaan orangtua/masyarakat mulai terbangun, sehingga promosi efektif dari kepuasan pelangan yang tersampaikan kepada calon pelangga berikutnya. Namun upaya promosi lainnya yang tetap dilakukan adalah promosi via sosial media seperti Facebook, Instagram, siaran di Up Radio laman webite www.upgris.ac.id/fip/pgpaud dan website penaprima.upgris.ac.id 


\title{
6. Pelaksanaa Produksi
}

Pelaksanaan produksi layanan usaha PENA PRIMA terdiri dari kegiatan pembelajaran, dan layanan jasa antar jemput siswa serta kegiatan ekstra kulikuler musik dan sekolah musik PNA PRIMA.berikut dideskripsikan proses produksi di TPA PENA PRIMA yang berupa kegiatan pembelajaran.

\section{a) Pembelajaran Tematik TPA PENA PRIMA}

Pembelajaran yang dilakukan terdiri dari dua kelompok besar yakni kelompok toodler yaitu kelompok belajar 0-2 tahun dan kelompok belajar besar untuk 3-5 tahun. Kegiatan pembelajaran minggu pertama bulan Januari, dilakukan dengan Bermain dan belajar mengenai Binatang sub Tema tata surya. Kegiatan bermain yang dilakukan anak-anak bersama guru adalah mengenal benda-bneda langit seperti bumi, bulan dan matahari, anak-anak menganal sebab akibat siang malam dan gejala alam lainnya yang dekat dan sederhana ssuai perkembangan anak.

Berbagai kegiatan dan stimulasi yang dirancang oleh guru dengan tata surya tersebut dilakukan dengan megunakan pendekatan saintifik. Pebdekatan saintifik dilakukan supaya guru dapat memilih pendekatan pembelajaran yang paling sesuai dengan cara belajar anak, dan karakteristik anak usia dini, cara belajar anak, dan prinsip pembelajaran PAUD. Adapun RPPM tema tatasurya dapat disajikan dalam tabel berikut

\section{RENCANA PELAKSANAAN PEMBELAJARAN MINGGUAN (RPPM) TPA PENA PRIMA USIA KB \\ TAHUN AJARAN 2018/2019}

\author{
Semester/Bulan/Minggu \\ : 2/Januari/Minggu Ke 5/28 Januari - 1 Februari \\ 2019 \\ Tema \\ Sub Tema \\ : Tata surya \\ Topik \\ Kelompok \\ Alokasi Waktu \\ : Bulan \\ : Bulan yang terang \\ : KB (usia 3-4) \\ : 150 menit x 5 hari \\ $\mathrm{KD}$ \\ $: 1.1 ; 2.1 ; 2.2 ; 3.3-4.3 ; 3.5-4.5 ; 3.6-4.6 ; 3.9-4.9 ; 2.5 ; 2.7 ; 2.11 ; 2.12 ; 3.2-$ \\ $4.2 ; 2.14 ; 3.10-4.10 ; 3.11-4.11 ; 3.12-4.12 ; 2.4$
}

Tabel 2. RPP

KD

\section{MATERI PEMBELAJARAN}

1.1. Mempercayai adanya Allah dengan ciptaan Tuhan

2.1 Memiliki perilaku yang mencerminkan hidup sehat.

- Perbedaan ciptaan Tuhan dan manusia

- Ucapan kalimat pengagungan kepada Tuhan

- Cuci tangan sebelum dan sesudah makan

- Cuci tangan selesai kegiatan pembelajaran

- Kebiasaan mencuci tangan dan menggosok gigi

2.2. Memiliki perilaku yang mencermin- kan sikap ingin tahu

3.3. Mengenal anggota tubuh,fungsi dan gerakannnya untuk pengembangkan motorik kasar dan motorik halus

- Eksplorasi berbagai mainan yang dibuat

- Kegiatan motorik kasar

- Kegiatan motorik halus

4.3. Menggunakan anggota tubuh untuk pengembangan motorik kasar dan halus

3.5.Mengetahui cara memecahkan masalah sehari-hari dan perilaku kreatif

4.5 Menyelesaikan masalah sehari-hari secara kreatif

- Dapat menyelesaikan permainan yang ada

- Aktif bertanya pada orang-orang di lingkungannya untuk memecahkan masalah sederhana

3.6.Mengenal benda-benda disekitarnya (nama, warna, bentuk, ukuran, pola, sifat, suara dan tekstur)

4.6.Menyampaikan tentang apa dan bagaimana benda-benda di sekitarnya yang dikenalnya (nama, warna, bentuk, ukuran, pola, sifat, suara, tekstur, fungsi dan ciri-cirinya )

- Nama-nama tata surya

- Bentuk (lingkaran, persegi, tak beraturan)

- Fungsi matahari dan bulan (menyinari bumi) 
melalui berbagai karya

3.9. Mengenal teknologi sederhana (peralatan rumah tangga, perlatan bermain, peralatan pertukangan, dll)

4.9. Menggunakan teknologi sederhana untuk menyelasaikan tugas dan kegiatannya (peralatan rumah tangga, peralatan bermain, peralatan pertukangan, dll)

2.5. Memiliki perilaku yang mencerminkan sikap percaya diri

- Alat teknologi sederhana sabar (mau menunggu giliran, mau mendengar jika orang lain berbicara)

- Sikap gigih untuk melakukan kegiatan tanpa bantuan

- Bercerita dan bernyanyi di depan kelas

- Menunggu giliran masuk lift

- Menunggu giliran mencuci tangan

- Mendengar bunda dan teman ketika berbicara/bercerita

2.11 Memiliki perilaku yang dapat menyesuaikan • Tidak mengganggu teman diri

2.12 Memiliki perilaku yang mencerminkan sikap - Menyelesaikan dan merapikan mainan tanggung jawab

2.6. Memiliki perilaku yang mencerminkan sikap taat terhadap aturan sehari-hari untuk melatih kedisiplinan

2.9. Memiliki perilaku yang mencerminkan sikap peduli dan mau membantu jika diminta bantuannya

2.10. Memiliki perilaku yang mencerminkan sikap menghargai dan toleran kepada orang lain

3.2 Mengenal perilaku baik sebagai cerminan akhlak mulia

4.2 Menunjukkan perilaku santun sebagai cerminan akhlak mulia

2.14. Memiliki perilaku yang mencerminkan sikap santun kepada orangtua, pendidik dan teman

3.10. Memahami bahasa reseptif (menyimak dan membaca)

4.10. Menunjukkan kemampuan berbahasa reseptif (menyimak dan membaca)

3.11. Memahami bahasa ekspresif (mengungkapkan bahasa secara verbal dan non verbal)

- Taat terhadap aturan main

- Mau menolong dan membantu teman

- Ucapan kata maaf bila berbuat salah

- Ucapan terimakasih

Menunjukkan kemampuan berbahasa ekspresif (mengungkapkan bahasa secara verbal dan non verbal)

3.12. Mengenal keaksaraan awal melalui bermain

4.12. Menunjukan kemampuan keaksaraan awal dalam berbagai bentuk karya

2.4. Memiliki perilaku yang mencerminkan sikap estetis

- Ucapan: nama-nama tata surya (matahari, bulan, bintang)

- Keaksaraan awal: m (Matahari) b (bulan)

- Kreativitas seni dan hasil seni (lukisan dan bernyanyi)

Tabel diatas berisi rencana kegiatan pembelajaran selama satu minggu atau yang dikenal dengan RPPM yang terbagi kedalam berbagai kegiatan untuk menstimulasi semua aspek pengembangan yakni nilai moral agama, sosial, bahasa kognitif, fisik motorik dan seni.kagiatan disajikan guru secara menarik dan menyenangkan sesuai dengan prinsip pembelajaran aktif. Guru perlu menciptakan banyak kegiatan menarik yang dapat membangkitkan rasa ingin tahu, memotivasi berpikir kritis dan kreatif pada anak. Anak didorong untuk menjadi pembelajar aktif, yaitu melakukan aktivitas belajar atas dasar ide anak, bukan hanya mengikuti instruksi atau arahan guru. Ketika menjadi pembelajar aktif, seluruh panca indera, anggota tubuh dan proses berpikir anak juga aktif. Pembelajaran yang aktif akan lebih banyak 
memberikan kesempatan kepada anak untuk melakukan dan terlibat langsung dalam kegiatan yang telah direncanakan oleh guru. Anak lebih banyak diberi kesempatan untuk mengamati, berdiskusi, mencoba, dan melakukan eksplorasi, sehingga mendapatkan lebih banyak informasi bermakna untuk membangun pengetahuan, sikap dan keterampilan. Pembelajaran aktif dapat terlaksana ketika anak lebih banyak diberi kesempatan untuk berinteraksi dengan dunia dan benda-benda nyata.

Beberapa dokumentasi kegiatan pembelajaran dengan tema tata surya dapat dilihat dalam dokumentasi dibawah ini.
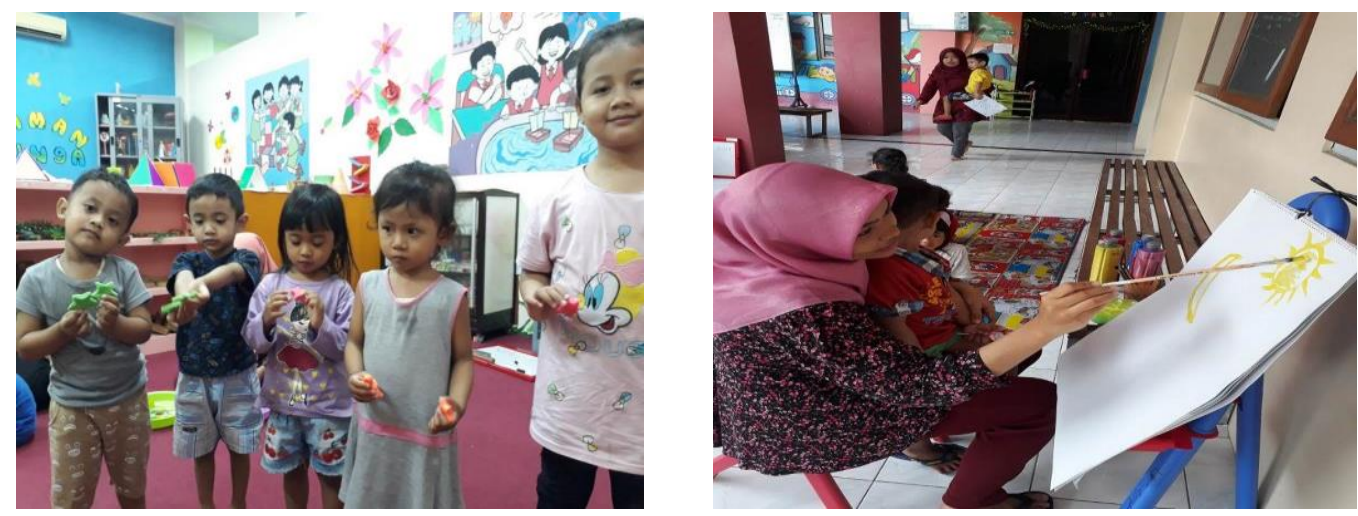

Gambar 2. Kegiatan anak mencetak binatang dengan media plastisin dan melukis tata surya

Kegiatan diatas dilakukan untuk memberikan pengalaman dan pengenalan terhadap benda langit yang ada di tata surya yaitu bintang. Dengan media yang plastisin, yang bertujuan sebagai pengembangan motorik kasar dan motorik halus anak, anak dapat mengenal bintang yang sering anak-anak tersebut lihat di malam hari jika cuaca nya cerah. Selain itu pengenalan bintang ini juga terintegrasi dengan pengenalan bentuk geometi sederhana.

Kegiatan bermain plastisin ini dilakukan dengan cara membentuk, sehingga menimbulkan bentuk. Media plastisin ini membuat anak suka berkreasi sehingga dapat mengembangkan kreativitasnya. Anak dilatih untuk menggunakan imajinasi untuk membuat atau menciptakan suatu bangunan atau benda sesuai dengan khayalannya seperti angka, abjad, binatang dan lain-lain. plastisin dapat melatih sekaligus mengembangkan kreativitas anak. Sebab, dengannya anak dapat melakukan aktivitas eksplorasi dalam membuat berbagai bentuk model secara bebas dan spontan. Bermain dengan plastisin, anak-anak dapat mengekspresikan kreativitas mereka dengan menemukan serta membuat gaya-gaya unik dari cara berekspresi masing-masing. Setiap hasil karya bermain dengan plastisin akan berbeda dari satu anak dan lainnya, sama halnya dengan perbedaan dalam penampilan maupun kepribadiannya masing-masing anak. Kegiatan lainnya tentang tata surya adalah bersama guru melukis matahari dan bulan,

b) Kegiatan Festival

TPA PENA PRIMA Sekolah Laboratorium PG PAUD menjadi salah satu inisiator pelaksana dan peserta festival Sarapan padat bernutrisi yang dilaksanakan paralel di tiga Kota Besar, yakni Surabaya, Jakarta dan Semarang. Dengan jumlah peserta sarapan padat bernutsi adalah 3000 anak kegiatan tersebut dilaksanakan pada tanggal 6 April 2019 bertempat di Auditorium Balairung Universitas PGRI Semarang. Festival ini berisi kegiatan sarapan bersama secara masal, senam bersama, lomba menghias sarapan dengan roti gabungan anak dengan ibu serta dan diisi dengan penampilan dan kreasi anak-anak PAUD dari kota Semarang, festival sains dan DOKAR BOBO. Rekaman kagiatan tersebut dapat terlihat pada gambar dibawah ini
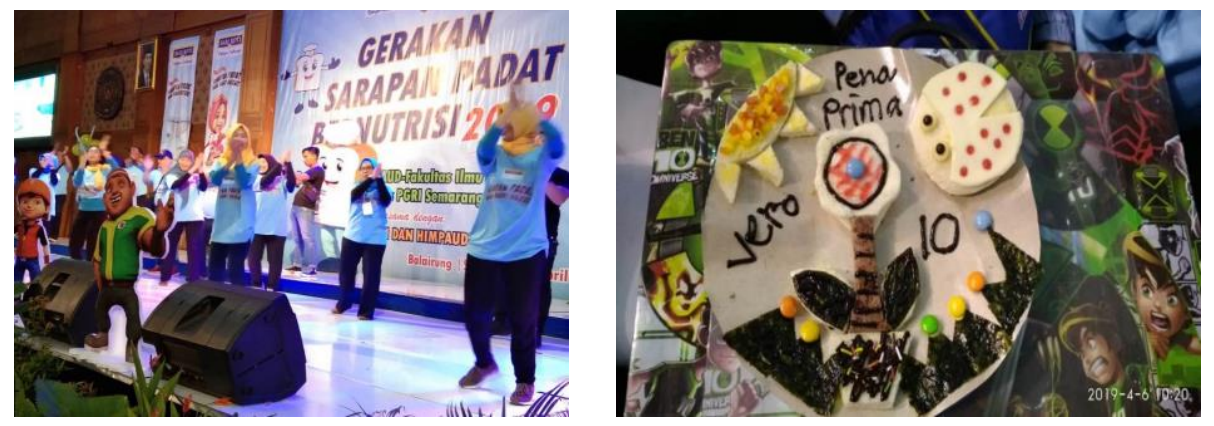

Gambar 3. Senam bersama dan contoh kreasi lomba menghias sarapan sari roti dengan peserta 
c) Kegiatan Puncak Tema

Untuk memberikan kebermaknaan pembahasan tema, maka pada setiap akhir tema perlu dikokohkan dengan puncak tema. Kegiatan puncak tema adalah kegiatan untuk memberikan kebermaknaan pembahasan tema, maka pada setiap akhir tema perlu dikokohkan dengan puncak tema. Kegiatan puncak tema bersifat menggembirakan, penguatan sikap, pengetahuan, keterampilan yang melibatkan berbagai pihak terutama orang tua/keluarga.
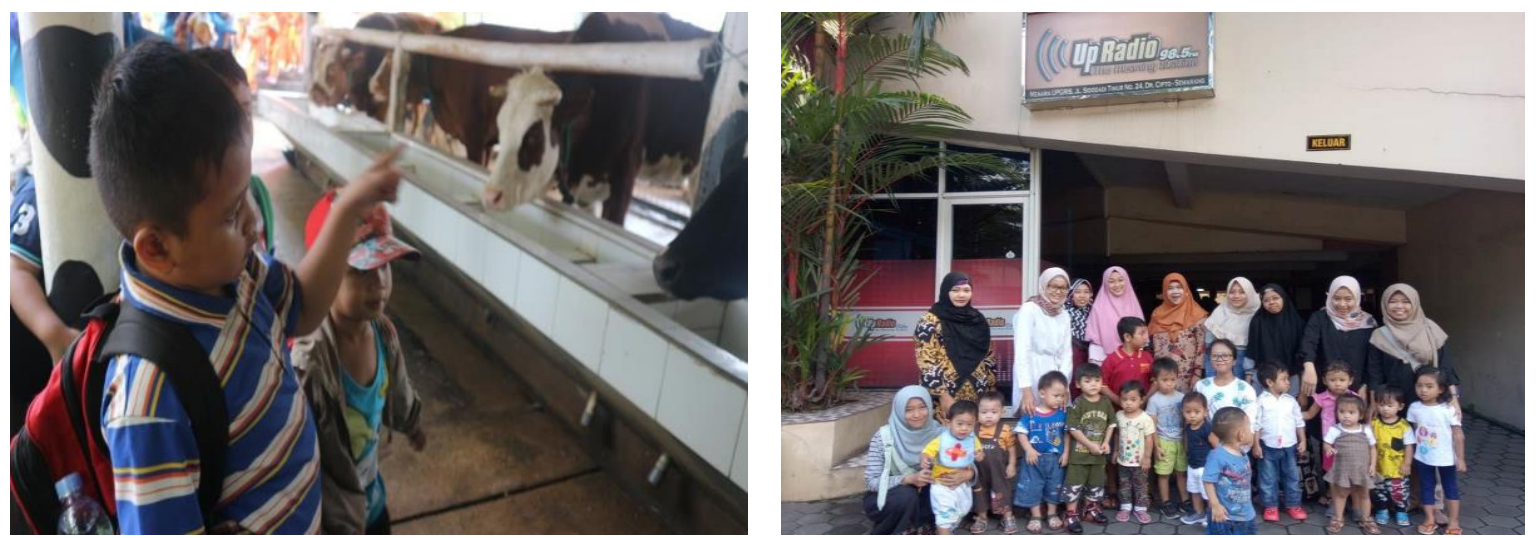

Gambar 4. Kunjungan Puncak Tema ke Peternakan dan ke Radio

d) Pelaksanaan Pentas Seni dan Pameran Hasil Karya

Kegiatan selanjutnya yang dilaksanakan TPA PENA PRIMA khususnya menyambut Bulan Ramadhan adalah kegiatan bazar dan kegiatan amal melalui pentas seni. Anak anak dengan didampingi gurunya membuat berbagai hasil karya dengan tema nuansa Ramadhan untuk kemudia dikumpulkan dan akan di buat bazar pada saat akhir ramadhan menjelang akhir pembelajaran. Kegiatan tersebut dimaksudkan selain untuk menyambut bulan Ramadhan dengan penuh suka cita, juga menumbuhkan rasa berbagi, berempati dan dan peduli antara keluarga besar TPA PENA PRIMA. Sebagai kegiatan puncak, hasil karya yang telah dibuat kemudian di display dan diadakan bazaar untuk seluruh keluarga anak-anak. Kegiatan tersebut juga di selingi dengan pentas seni yang menambah semarak parade ramadhan tersebut.
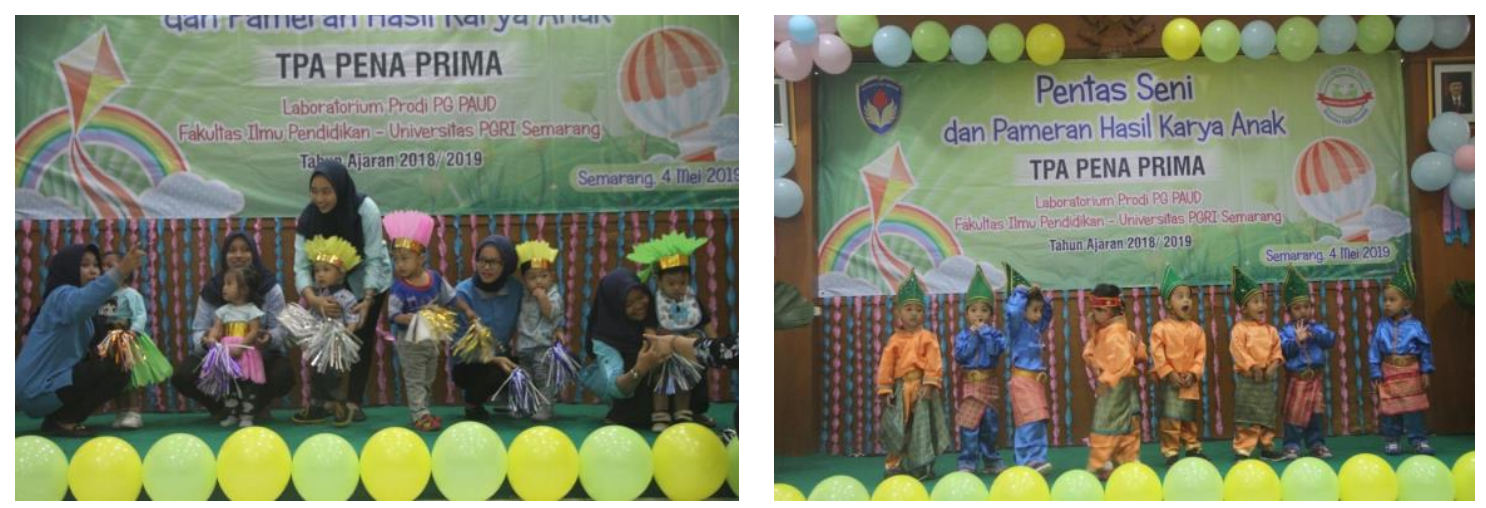

Gambar 5. kegiatan Pentas seni

Dalam kegiatan Pentas seni tersebut, anak-anak mencoba tampil di depan orantua, keluarga dan teman-teman melatih rasa percaya diri, keberanian dan potensi seninya melalui pentas bernyanyi bersama, menari dan gerak lagu. Seteleh pentas seni, orang ua bersama anak menuju tempat pameran hasil karya untuk melihat dan mengapresiasi hasil karya anak-anak tersebut. Para orang tua diberikan satu tas untuk membwa hasil karya anaknya. Hasil karya tersebut akan di apresiasi dalam bentuk amal/infaq untuk kemudian disalurkan ke lembaga amil zakat terdekat.

\section{e) Sekolah Musik PENA PRIMA}

Kegiatan produksi layanan usaha berikutnya yaitu sekolah musik PENA PRIMA. Kegiatan produksi meliputi pelaksanaan ekstrakulikuler bermain musik bagi anak-anak TPA PENA PRIMA dan les musik bagi 
anak usia dini dari masyarakat luar. Kegiatan ekstra kulikuler bermain musik di TPA PENA PRIMA dilakukan setiap hari senin jam 09.00-10.30 WIB. Kegiatan bermain musik yang dilaksanakan bervariasi setiap minggu.

Kegiatan bermain musik menjadi salah satu unggulan dari TPA PENA PRIMA. Selain itu menjadi salah satu kegiatan yang paling disenangi anak-anak. Setiap minggu anak-anak mendapat stimulasi bermain musik dan bernyanyi/vokal yang berbeda, anak-anak dikenalkan dengan bermain drum, bermai keayboard, bermain angklung dan bermain perkusi sederhana. Beberapa rekaman kegiatan bermain musik tersaji dalam gambar dibawah ini.
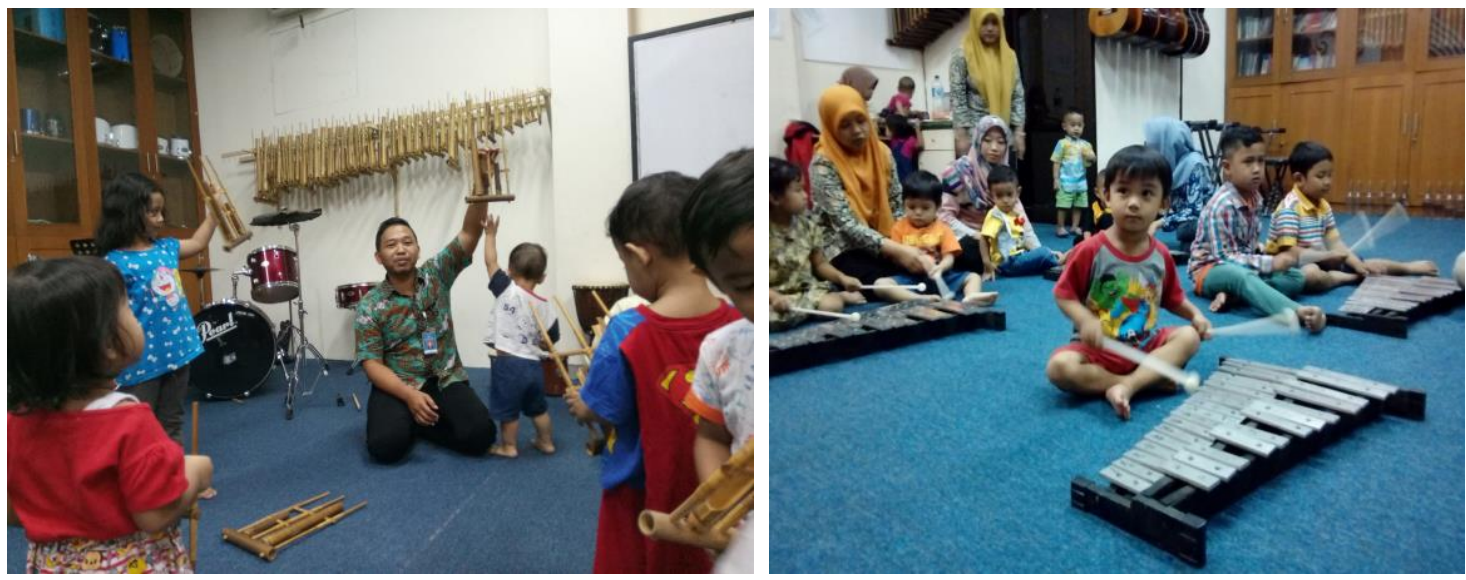

f) Publikasi

Gambar 8. Kegiatan bermain ekstra kulikuler Angklung dan xilophone

Kegiatan Publikasi PPUPIK PENA PRIMA yang telah dilakukan adalah, publikasi pada media elektronik, Faceboook dan Instagram. Publikasi lain yang akan dilakukan melalui Opini pada media cetak, submit artikel pengabdian untuk di presentasikan dalam seminar internasional hasil penelitian dan Pengabdian LPPM Universitas PGRI Semarang bulan Oktober 2019 mendatang. Proseding konferensi internasional anak usia dini di Universitas Pendidikan Indonesia pada bulan November 2018. Selain itu tim sudah mendaftarkan merek dagang "PENA PRIMA" pada Pusat HAKI untuk diperoleh hak ciptanya. Publikasi artikel pada jurnal nasional, akan tim pengabdi publikasikan pada Jurnal Pengabdian Universitas Wahid Hasyim (Unwahas), Jurnal AUDI (Universitas Sriwijaya).

\section{g) Evaluasi}

Evaluasi merupakan hal yang sangat penting dan tidak dapat terpisahkan dalam kegiatan PPUPIK ini. Evaluasi bertujuan untuk merefleksikan kegiatan yang telah berjalan, apakah sudah sesuai dengan rencana dan hasil yang diperoleh sudah memenuhi target yang ditentukan. Pelaksanaan evaluasi umum terkait ketiga layanan usaha dilakukan secara rutin selama satu bulan sekali bersama tim pengabdi, sedangkan evaluasi kegiatan layanan usaha TPA, sekolah musik TPA PENA PRIMA antar jemput siswa dilakukan dua minggu sekali. Selain itu kegiatan evaluasi berupa briefing, dilakukan setiap hari untuk memulai rutinitas layanan operasional. Dengan kegiatan evaluasi rutin itu, diharapkan layanan usaha PENA PRIMA berjalan lancar.

\section{Simpulan dan saran}

Berdasarkan kegiatan yang telah dilaksanakan dapat disimpulkan sebagai berikut ini:

1). Bussines plan PPUPIK telah tersusun secara terperinci, 2) Memiliki tempat dan fasilitas TPA PENA PRIMA yang ramah anak (1ruang kantor, 2 kelas, 2 ruang tidur, 1 ruang tengah dan dapur, halaman bermain dan 1 toilet), set alat edukasi akademik, penambahan fasilitas bermain untu TPA PENA Prima. 3). Jumlah peserta didik tetap yang terdaftar dan aktif sebanyak 30 anak, dan 17 anak kelompok besar, 13 anak kelompok kecil 4). Memiliki 5 pendidik TPA yang terampil dan bersertifikat pelatihan dan pengasuhan BATITA. 6). Persiapan mengajukan akreditasi kepada Badan Akredtasi nasional PAUD dan PNF (BAN PAUD PNF) melalui laman SISPENA 7. Jumlah murid sekolah musik pena prima 8 anak dan 7). Jumlah murid untuk kelompok bermain PENA PRIMA 17 anak Selanjutnya saran yang dapat diberikan adalah untuk selalu meningkatkan mutu dan kualitas pelayanan TPA PENA PRIMA sebagai Sekolah Laboratorium Program Studi PG PAUD sehingga dapat menjadi contoh penerapan TPA yang ramah anak. 


\section{Daftar Rujukan}

Direktorat Jenderal Pendidikan Anak Usia Dini, Nonformal dan Informal. 2013. Norma, Standar, Perosedur dan kriteria (NSPK. Petunjuk Teknis penyelenggaraan Taman Penitipan Anak. Direktorat Pembinaan Pendidikan Anak Usia Dini. Kementrian Pendidikan dan Kebudayaan

Direktorat Riset dan Pengabdian kepada Masyarakat. 2016. Panduan Pelaksanaan Penelitian dan Pengabdian kepada Masyarakat di Perguruan Tinggi edisi X. Kementrian Riset, Teknologi dan Pendidikan Tinggi.

Lwin, May, dkk . 2008 . How to Multiply Your Child's Intelligence. Jakarta : PT. Indeks.

Salinan Peraturan Menteri Kebudayaan dan Kebudayaan No. 137. Tahun 2014. Standar Tingkat Pencapaian Perkembangan Abak Usia Dini.

Sulistyanto, Yuli, dkk. 2016. Buku Suplemen Penyelenggaraan Taman Penitipan

Anak Berperspektif Hak Anak. Badan Pemberdayaan Perempuan dan Perlindungan Anak dan keluarga Berencana (BP3KAB). Provinsi Jawa Tengah.

Seefeldt, Carol \& Barbara A. Wasik. (2008). Pendidikan Anak Usia Dini Menyiapkan Anak Usia Tiga, Empat, dan Lima Tahun Masuk Sekolah. Jakarta : PT. Indeks.

Sousa, David A. (2012). Bagaimana Otak Belajar. Jakarta : PT. Indeks.https://madaniah.co.id/manfaatbelajar-musik-bagi-anak-sejak-usia-dini/

TK.Lab.School.UPI. 2015. Rasional Penyelenggaraan Daycare. [online]. Tersedia dalam http://tk.labschool.upi.edu/daycare/. Tanggal akses 21 April 2016.

Undang-Undang Nomor 13 tahun 2013 Tentang Ketenaga kerjaan

Wijaya, Wirawan Surya. 2013. Analisis Pengembangan Produk Pada Perusahaan Tepung Terigu Di Surabaya . Jurnal Agora Vol. 1, No. 1, (2013) 